\title{
SPATIAL ANALYSIS OF POVERTY AND HAPPINESS PROFILES IN SPECIAL REGION OF YOGYAKARTA USING SMALL AREA ESTIMATION METHOD
}

\author{
Shafiera Rosa El-Yasha ${ }^{1}{ }^{*}$, Mayang Rizky ${ }^{2}$, Totok Wahyu Wibowo ${ }^{3}$, Sudaryatno ${ }^{4}$ \\ ${ }^{1}$ Universitas Gadjah Mada, Dept. Geographic Information Science, Yogyakarta 55281, Indonesia - shafiera.rosa.e@mail.ugm.ac.id \\ ${ }^{2}$ SMERU Research Institute, Jakarta 10330, Indonesia - mrizky@ smeru.or.id \\ ${ }^{3}$ Universitas Gadjah Mada, Dept. Geographic Information Science, Yogyakarta 55281, Indonesia - totok.wahyu@ugm.ac.id \\ ${ }^{4}$ Universitas Gadjah Mada, Dept. Geographic Information Science, Yogyakarta 55281, Indonesia - sudaryatno@ugm.ac.id
}

KEY WORDS: Spatial Analysis, Poverty Map, Happiness Map, Small Area Estimation

\begin{abstract}
:
In March 2017, the Province of Special Region of Yogyakarta (DIY Province) has poverty line of IDR 374,009, percentage of poor people (13.03\%) and Gini index (0.432) above the national average (IDR 374,478; 10.64\%; 0.393). The result of happiness index in 2017 shows the position of DIY Province (72.93\%) is above average of national happiness index (70.69\%). Scatterplot between happiness index and percentage of poor people in Indonesia in 2017 shows that DIY Province is on first quadrant. This marks the high level of happiness along with high percentage of poor people. Small area estimation method developed by Elbers et al (known as ELL method) is used to determine spatial characteristics of poverty and happiness profiles in DIY Province. This study used village census data (Podes) 2018; Susenas March 2017 and SPTK 2017 as survey data. There are twenty three household variables and another five variables that are significant to poverty and happiness models at urban and rural provincial level. Rural regency areas dominates high poverty profile (FGT0 $0.0491-0.1076$ ), low happiness profile (FTG0 $0.0087-0.0124$ ), and inequality of happiness profile (Gini index 0.0847 - 0.0923). Urban regency areas dominates low poverty profile (FTG0 $0.0082-0.0491$ ), high happiness profile (FTG0 $0-0.0087$ ), and perfect equality of both income (Gini index $0.3048-0.3604$ ) and happiness profiles (Gini index 0.0624 - 0.0847). Yogyakarta City has happiest and wealthies profiles, whereas Gunung Kidul regency urban area has perfect equality of both income and happiness profiles.
\end{abstract}

\section{INTRODUCTION}

Poverty profile (BPS, 2018a; 2018b) and happiness index (BPS, 2017) published by Statistics Indonesia (BPS) presents the image regarding the poverty and happiness levels in each Province of rural and urban areas in Indonesia. In March 2017, Special Region of Yogyakarta (DIY) Province has poverty line (IDR 374,009), percentage of poor people (13.02\%) and Gini index (0.432) above the national average (IDR 374,478; $10.64 \%$; 0.393). In 2017, the results of happiness index show the position of DIY Province $(72.93 \%)$ is above the national average of happiness index $(70.69 \%)$.

Figure 1 shows scatterplot between happiness index (Y-axis) and poor people (X-axis) in Indonesia in 2017. Red circle shows DIY Province on first quadrant where $\mathrm{X}$-axis and $\mathrm{Y}$-axis are positive. Both axes are positive indicates the high level of happiness along with high percentage of poor people.

BPS measured poverty based on primary needs which can be fulfilled by an individual. Hence, an individual is considered as poor when he/she is not economically capable to fulfill the primary needs of consumption and non-consumption that is measured in terms of expenses. Incapability to fulfill both types of needs is shown in poverty line. Poor people is people who has an average per capita per month below poverty line.

BPS uses Gini index to measure expenses inequality and expenses percentage inequality in Indonesia. Inequality is a condition where economic development in one area is not equal. Gini index has a range of $0-1$. The closer it gets to 0 , shows an ideal equality whereas if it is closer to 1 , shows a bad equality.
BPS defines happiness as a concept from the result of life evaluation which pictured the living condition of a good life and eudemonia. This concept means life satisfaction, affect, and eudemonia. BPS measures happiness index using three weighted dimension which are life satisfaction (personal and social), affection and eudemonia. Happiness index has the range of 0-100. The higher index value, the higher level of happiness.

Happiness index is arranged based on the judgement of an individual to their life satisfaction scale. Life satisfaction scale has the range of $0-10$, where the higher the value means a higher life satisfaction. BPS gives life satisfaction scale for each indicator of happiness index and also, gives life satisfaction scale as a whole. Score 5 (five) on scale is middle score where an individual can get low score of life satisfaction or high score of life dissatisfaction. The final index is multiplied by 10 hence happiness index with 50 scores is the middle score of happiness index.

Various studies have proven that there is a correlation between poverty and happiness (Easterlin, 1974 adopted from Rahayu, 2016; Stanca, 2010). Location or distribution of poverty and happiness area can be analyzed by its spatial relationship based on the factors that affect the improvement of population welfare which is not only in terms of economy (expenses and income).

Conventionally, poverty mapping uses census and survey data as the primary source. Both are published periodically in a specific time. Despite it requiring more time, cost, and energy, census and survey data are still excellent in conventional economy-social mapping. On the other hand, there are many developing mapping methods of poverty that uses economysocial statistic that is used to balance the lack of conventional poverty mapping (Elbers et al, 2003). 


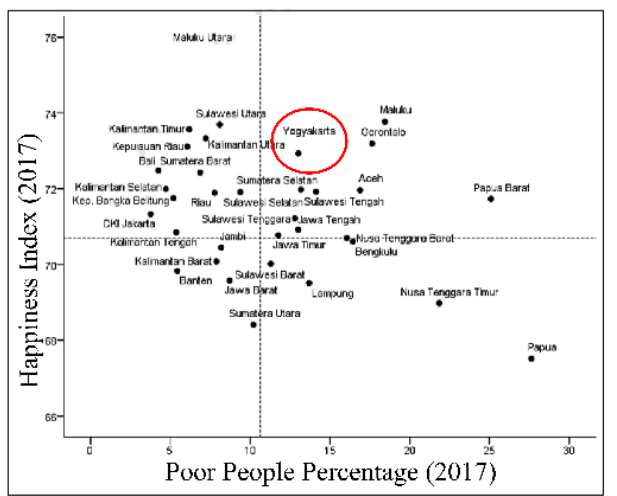

Figure 1. Scatterplot of Happiness index and Poor people percentage by province in Indonesia Source: BPS 2017

World Bank applies poverty mapping method using a combination of excellence from census and household survey data to achieve poverty map in the smallest geographic area by both data sources. This method is known as Small Area Estimation (SAE) which is developed by Elbers et al (2003), which is now knows as ELL method.

Small Area Estimation (SAE) is a method which combines the profit of survey and census data usage to develop the estimation of population parameters. Usually, in terms of consumption and income level along with decreasing the level of distribution from that estimation unit (Elbers et al, 2002; 2003). Elbers et al (2003) uses the excellence of census and survey data to create a consumption equation model. This model is aimed to estimate the poverty with a wide scope of area and information which can be held by responsible statistically. The consumption equation model is already equipped with standard errors which completes the consumption model.

SAE has been often applied in poverty mapping. This research uses SAE in ELL method to map the population social condition which is happiness level. The big picture of this research is to estimate poverty and happiness using ELL method. Then, the result of model estimation is classified into four classifications to picture the poverty and happiness profile. Query on the classification of the two models is used to produce a profile map of poverty and happiness. These maps then will be used for spatial analysis and spatial modelling.

\section{STUDY AREA AND DATASET}

\subsection{Study Area}

Area of study is located in Special Region of Yogyakarta (DIY) Province (Figure 2). Geographically, DIY Province is located between $7^{\circ} 33^{\prime}-8^{\circ} 12^{\prime}$ south latitude and $110^{\circ} 00^{\prime}-110^{\circ} 50^{\prime}$ east longitude. Administratively, DIY Province has a total area of $3,185.8 \mathrm{~km}^{2}$ consisting of one city, four regencies, 78 districts and 438 villages.

Figure 3 presents the visualization of hierarchy level in Indonesia. Starting from the highest level which is country and lowest level which is village. City hierarchy is equal to regency hierarchy. Sub-district hierarchy equals to village. Sub-district and village are the lowest level of hierarchy. Urban classification is the term for sub-district whereas rural classification is the term for village.

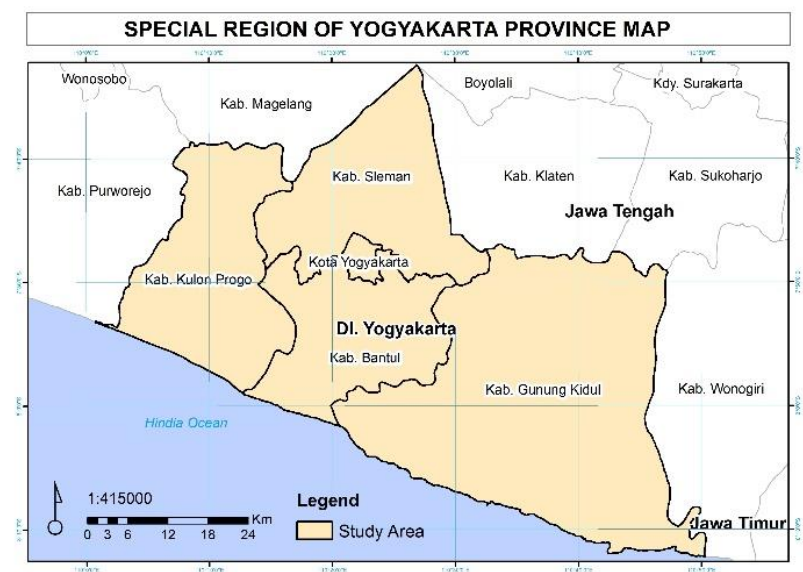

Figure 2. Map of Special Region of Yogyakarta (DIY) Province

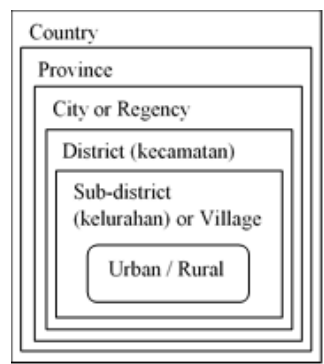

Figure 3. Hierarchy level in Indonesia

\subsection{Dataset}

This research uses three primary sources: village potential data (Podes) 2018, National Economy Social Survey (Susenas) in March 2017, and Survey of Happiness Level Measurement (SPTK) 2017. Additional data used are Village Master File (MFD) 2010, BPS policy regarding statistical work area (Wilkerstat) 2017 and village administration border in DIY Province. MFD is used to provide area hierarchy ID including urban and rural classifications. Wilkerstat is used to see the latest development conditions of region in 2017, whether there are changes in urban and rural area level (merge and separation).

The three primary sources, MFD and Wilkerstat can be retrieved from Statistics Indonesia (BPS) and village administration border in shapefile format can be retrieved from Geospatial Information Agency (BIG).

Podes is village level census, and in this research it is used as an alternative of population data census. In estimation model, dependent variable and household characteristic can be retrieved from Susenas and SPTK. Dependent variable of poverty estimation is log per capita expenditure. Dependent variable of happiness estimation is overall life satisfaction scale. All three primary sources offer various hierarchy levels. Podes is used to represent village data level. Susenas is published at urban and rural province and city/regency level. SPTK is published at urban and rural province level.

\section{METHODOLOGY}

In overall, methods concerning with building dataset, estimation model, and spatial analysis. This research uses QGIS 2.18 and PovMap 2.0 softwares. Detailed explanation regarding research methodology are as follows: 


\subsection{Small Area Estimation}

Estimation calculation on both models (poverty and happiness) is carried out on urban and rural Province level (table 1, ID 134 and 234). This is caused by population data available only in aggregation level (Podes 2018) and Susenas samples schemes was made to represent data up to rural and urban regency level while SPTK sample schemes was made to represent data up to rural and urban provincial level. Based on Elbers et al (2003), estimation model can be developed using the following model:

$$
\ln \mathrm{Y}_{\text {ch }}=\mathrm{E}\left[\ln \mathrm{Y}_{\text {ch }} / \mathrm{X}_{\text {ch }}\right]+\mu_{\text {ch }}
$$

where $\mathrm{c}=$ subscript for province cluster, $\mathrm{h}=$ subscript for rural and urban village-h on cluster-c, $\ln \mathrm{Y}_{\mathrm{ch}}=$ logarithm of per capita expenditure or logarithm of overall satisfaction life scale variable village-h cluster-c, $X_{\mathrm{ch}}=$ household characteristic village-h cluster-c, $\mu_{\mathrm{ch}}=$ vector of disturbance. Location variables are not involved in equation 1 because survey data does not represent the whole population in census data area. Hence, the remaining of estimation 1 is filled with locational variance:

$$
\mu_{c h}=\eta_{c}+\varepsilon_{c h}
$$

where $\eta_{\mathrm{c}}$ is level of error in cluster term and $\varepsilon_{\mathrm{ch}}$ is level of error in household term. GLS regression calculations are needed because it uses OLS to obtain " $\beta$ " in equation 3. The matrix structure of GLS variances is a diagonal block. Linear approximation from equation 1 or beta model is:

$$
\ln \mathrm{Y}_{\text {ch }}=\mathrm{X}_{\mathrm{ch}} \beta+\mu_{\text {ch }}
$$

To obtain small area estimation value and it standard error, the model is simulated to population with bootstrap a hundred times. Simulation model is defined as in equation (4). In simulation stage, it's important that population/census data have complete hierarchy ID to the aggregate needed.

$$
\ln \hat{y}_{c h}=x_{c h} \bar{\beta}+\tilde{\eta}_{c}+\tilde{\varepsilon}_{c h} \text { where } \beta \times N\left(\beta, \Sigma_{z}\right)
$$

Regressor variables have to be available in census data and survey data and measured with the same method so that aggregation model can run and get accurate estimation result. Therefore, further analysis regarding definition and simple statistic comparison are required on each variable between census and survey data. For further explanation regarding this method, see Elbers et al (2002; 2003).

Census and survey data needs to be compiled into an array data. Compilation is done by matching it according to hierarchy ID. Determination of hierarchy ID can be based on needs and ID availability on census and survey data. Hierarchy ID used to compile dataset on this research are cluster hierarchy ID (table 1) and household ID. Additional household ID in dataset can be used to simplify PovMap 2.0 software when carrying out ID truncate.

\begin{tabular}{|l|l|}
\hline \multicolumn{1}{|c|}{ ID } & \multicolumn{1}{c|}{ Description } \\
\hline \multicolumn{1}{|c|}{ Urban } \\
\hline 134 & Special Province of Yogyakarta \\
\hline 13401 & Regency of Kulon Progo \\
\hline 13402 & Regency of Bantul \\
\hline 13403 & Regency of Gunung Kidul \\
\hline 13404 & Regency of Sleman \\
\hline
\end{tabular}

\begin{tabular}{|l|l|}
\hline 13471 & City of Yogyakarta \\
\hline 234 & Rural \\
\hline 23401 & Recial Province of Yogyakarta \\
\hline 23402 & Regency of Bulon Progo \\
\hline 23403 & Regency of Gunung Kidul \\
\hline 23404 & Regency of Sleman \\
\hline \multicolumn{2}{|c|}{ Table 1. Hierarchy ID Model }
\end{tabular}

Explanatory variables used in the estimation model are chosen from variable which contributes significantly on models. Selection of explanatory variables using stepwise regression method (entry $=0.2$ and stay $=0.15$ ). We use poverty line of urban and rural province and score 5 on overall life satisfaction scale as happiness threshold.

\subsection{Spatial Analysis}

In this research, we use FGT0 and Gini index to determine spatial profiles. FGT0 shows individual proportion which has expenses and happiness level below the threshold. Gini index shows the population disparity level on the expenses and life satisfaction scale.

Estimation results on both models are classified into four classes. Classification using geometrical interval method with color gradation symbol. All four classifications are given labels according to the models (table 2). Query on classification of the

\begin{tabular}{|c|c|c|c|c|}
\hline \multirow{2}{*}{$\begin{array}{c}\text { Spatial } \\
\text { profiles } \\
\text { based } \\
\text { on } \\
\text { FGT0 }\end{array}$} & $\begin{array}{l}\text { Poorest } \\
\text { area }\end{array}$ & Poor area & Rich area & $\begin{array}{c}\text { Very Rich/ } \\
\text { wealthiest } \\
\text { area }\end{array}$ \\
\hline & $\begin{array}{c}\text { Least } \\
\text { Happy } \\
\text { area }\end{array}$ & $\begin{array}{l}\text { Unhappy } \\
\text { area }\end{array}$ & $\begin{array}{c}\text { Happy } \\
\text { area }\end{array}$ & $\begin{array}{l}\text { Happiest } \\
\text { area }\end{array}$ \\
\hline \multirow{2}{*}{$\begin{array}{l}\text { Spatial } \\
\text { profiles } \\
\text { based } \\
\text { on Gini } \\
\text { index }\end{array}$} & $\begin{array}{c}\text { Perfect } \\
\text { inequality } \\
\text { of income }\end{array}$ & $\begin{array}{c}\text { Most } \\
\text { inequal of } \\
\text { income }\end{array}$ & $\begin{array}{c}\text { Most } \\
\text { equal of } \\
\text { income }\end{array}$ & $\begin{array}{l}\text { Perfect } \\
\text { equality of } \\
\text { income }\end{array}$ \\
\hline & $\begin{array}{c}\text { Perfect } \\
\text { inequality } \\
\text { of } \\
\text { Happiness }\end{array}$ & $\begin{array}{l}\text { Most } \\
\text { inequal of } \\
\text { Happiness }\end{array}$ & $\begin{array}{c}\text { Most } \\
\text { equal of } \\
\text { Happiness }\end{array}$ & $\begin{array}{c}\text { Perfect } \\
\text { equality of } \\
\text { Happiness }\end{array}$ \\
\hline
\end{tabular}
two models is used to produce a profile map and to determine the spatial characteristics of poverty and happiness profiles in DIY Province.

Table 2. Spatial Analysis Classifications

\section{RESULT AND DISCUSSIONS}

Estimation calculation at rural and urban province level and population data only available at aggregation level (Podes 2018) caused the need to readjust on some terms. Readjustment meant in this case are readjustment on weight and household size. Weight and household size can only be retrieved in survey data and has different values for each household.

Readjustment of weight on Susenas and SPTK data are carried out by calculating the average weight of each household on urban and rural province aggregation level. The weighting problems in models are not expected to appear because estimation is applied at that level (Suryahadi et al, 2003). Survey weighting is required to represent the population. Meanwhile, readjustment of household size is carried out by calculating average of household size sum based on rural and urban province level. 
Hierarchy ID formulation used is based on Regulation of Statistics Indonesia (Perka BPS) which is village master file (MFD) 2010 and statistical work area (Wilkerstat) 2017. Based on the matching of MFD 2010 data and Wilkerstat 2017, there are no changes in the area (merge and separation) in DIY Province, both in urban and province level. There are nine hierarchies' regency/city of urban rural and two hierarchies' province of urban and rural (table 1). Each hierarchy consist two aggregations which are urban and rural areas except Yogyakarta City which only has urban aggregation.

Household member unit are represented with two variables which are occupation sector and cellular owner. Each household member has various occupation sector hence an individual is picked, household head, to represent characteristics of one household unit. Household unit are represented with twelve variables. Additionally, some variables regarding the surrounding environmental conditions are taken into consideration. Enviromental unit are represented with six variables.

Variables have to be available in census and survey data, measured and defined with the same method. Detailed explanation regarding this step can be seen in Zhao and Lanjouw (n.d). All three data sources used are from one institution therefore there will be no difference in definition of a term on the questions and answers of the questionnaire.

Census and survey data variables are further developed to obtain same type of data, which is categorical or continuous data. If the type of census data is continuous, the type of survey data has to be continuous and vice versa. Due to presence of difference in the questionnaire structure of census and survey data, this caused variables available to not have same data type. Same data type made variables from both data to be compared statistically.

To obtain same data type as well as characteristics of each variables comprehensively, new columns are created regarding specific answers of questionnaire about a certain variable. The content of new column is binary value $(0=$ no and $1=$ yes $)$ which shows response based on referred variables. This caused all variables has categorical data type.

Comparison of statistic summary (mean and standard deviation) between census and survey data is used to find out whether both data captures the same thing. Comparison of statistic summary is done according to estimation aggregation level (urban and rural province). Based on result of comparison between statistic of census and survey, the chosen variable is comparable and therefore can be used in estimation calculation.

Estimation calculation for rural and urban area should be applied separately (Suryahadi et al, 2003; Zhao and Lanjouw, n.d). In this research, aggregation calculation of urban and rural area province is not done separately. This is due to variation of epsilon (VarEp) on urban model Podes - Susenas being too small, hence GLS are not produced. Combination of estimation calculations between urban and rural areas resulted in similar regressor variables for both areas.

Explanatory variable to calculate the estimation is a variable which has contributed significantly to the models. OLS and GLS values as well as standard error of explanatory variables which has contributed significantly can be seen in Appendix 1 for Podes - Susenas and Appendix 2 for Podes - SPTK. Description of explanatory variables which has contributed significantly to the models can be seen in Appendix 3. There are twenty three variables that contributed significantly to poverty model and five variables for happiness model at urban and rural provincial level.

Parameter estimation which has been done is simulated in census data. Simulation stage is when bootstrapping process is carried out to fix accuracy level of estimation on various application of aggregations. Output estimation are urban and rural for provincial and regency/city aggregation levels. Table 3 shows estimation results of poverty based on FGT0 and Gini index along with their standard errors. Table 4 shows estimation results of happiness based on FGT0 and Gini index along with their standard errors.

\begin{tabular}{|c|c|c|c|c|}
\hline ID & FGT0 & SE & GINI & SE \\
\hline \multicolumn{5}{|c|}{ Urban } \\
\hline 134 & 0.0181 & 0.0102 & 0.3708 & 0.0194 \\
\hline 13401 & 0.0213 & 0.0389 & 0.3302 & 0.0627 \\
\hline 13402 & 0.0252 & 0.0213 & 0.371 & 0.0356 \\
\hline 13403 & 0.025 & 0.0533 & 0.3048 & 0.0741 \\
\hline 13404 & 0.0175 & 0.0166 & 0.3742 & 0.0281 \\
\hline 13471 & 0.0082 & 0.014 & 0.3424 & 0.0384 \\
\hline \multicolumn{5}{|c|}{ Rural } \\
\hline 234 & 0.0903 & 0.0168 & 0.3714 & 0.0176 \\
\hline 23401 & 0.0803 & 0.0295 & 0.3625 & 0.0285 \\
\hline 23402 & 0.0571 & 0.0469 & 0.3723 & 0.0641 \\
\hline 23403 & 0.0986 & 0.025 & 0.3523 & 0.0229 \\
\hline 23404 & 0.1076 & 0.062 & 0.3771 & 0.0612 \\
\hline
\end{tabular}

Table 3. Poverty Estimation Result of Province and Regency/City level

\begin{tabular}{|c|c|c|c|c|}
\hline ID & FGT0 & SE & GINI & SE \\
\hline \multicolumn{5}{|c|}{ Urban } \\
\hline 134 & 0.005 & 0.0057 & 0.0821 & 0.0064 \\
\hline 13401 & 0.0053 & 0.0205 & 0.0797 & 0.0174 \\
\hline 13402 & 0.007 & 0.012 & 0.0847 & 0.0102 \\
\hline 13403 & 0.005 & 0.0246 & 0.0655 & 0.0198 \\
\hline 13404 & 0.0065 & 0.0102 & 0.0891 & 0.0099 \\
\hline 13471 & 0 & 0 & 0.0624 & 0.0088 \\
\hline \multicolumn{5}{|c|}{ Rural } \\
\hline 234 & 0.0109 & 0.0072 & 0.0923 & 0.0072 \\
\hline 23401 & 0.011 & 0.0122 & 0.0923 & 0.0099 \\
\hline 23402 & 0.0124 & 0.024 & 0.0894 & 0.0164 \\
\hline 23403 & 0.0107 & 0.01 & 0.0908 & 0.008 \\
\hline 23404 & 0.01 & 0.0252 & 0.0887 & 0.0176 \\
\hline
\end{tabular}

Table 4. Happiness Estimation Result of Province and Regency/City level

Estimation results map of poverty and happiness based on FGT0 and Gini index are divided into four classifications. In the first classification, FGT0 shows lowest proportion of population distribution below poverty line and life satisfaction scale threshold while Gini index shows perfect equality of income and happiness. In the fourth classification, FGT0 shows highest proportion of population distribution below poverty line and overall life satisfaction scale threshold while Gini index shows perfect inequality of income and happiness.

Figure 4 show poverty estimation map and Figure 5 show happiness estimation map based on FGT0 value. Both maps are displayed at rural and urban regencies/city level. The classification is divided into four based on geometrical interval method. The first classification is shown with brightest color and the fourth classification is shown with darkest color. 
Poverty first classification $(0.0082-0.0250)$ based on FGT0 shows lowest individual proportion which has expenses level below the poverty line. This classification is considered as Very Rich/wealthiest area classification. The fourth classification $(0.0835-0.1076)$ shows highest individual proportion which has expenses level below poverty line. This classification is considered as Poorest Area classification, and vice versa. Areas which are considered in Very Rich Area are areas with ID 13401, 13404, 13471. Areas considered as Rich Area are areas with ID 13402 and 13403. Areas considered as Poor Area are areas with ID 23401 and 23402. Lastly, areas considered as Poorest Area are areas with ID 23403 and 23404.

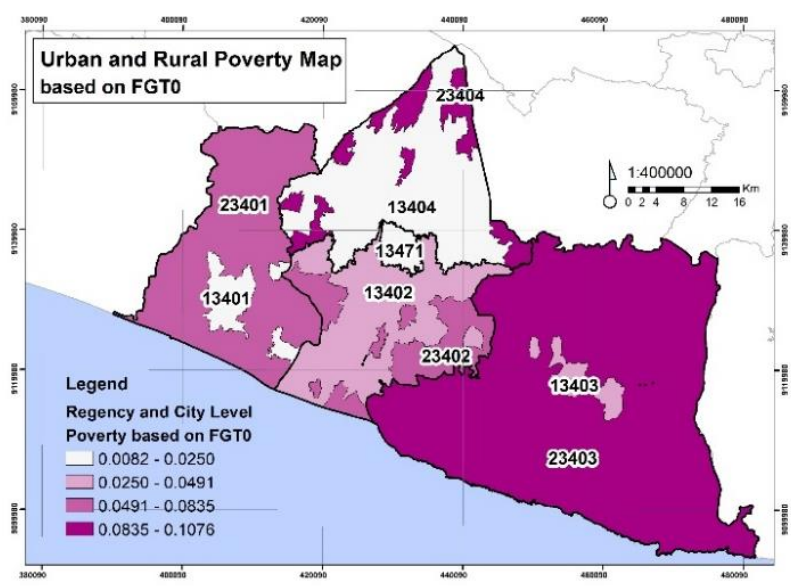

Figure 4. Poverty Map of DIY Province based on FGT0

Happiness first classification (0.0000 - 0.0052) based on FGT0 shows lowest individual proportion which has happiness level below threshold of overall life satisfaction scale. This classification is considered as Happiest Area. The fourth classification (0.0109 - 0.0124) shows a highest individual proportion which has happiness level below threshold of overall life satisfaction scale. This classification is considered as Least Happy Area, and vice versa. Areas which are considered as Happiest Area are areas with ID 13403 and 13471. Areas considered as Happy Area are areas with ID 13401, 13402, 13404. Whereas areas which are considered as Unhappy Area are ID 23403 and 23404. Lastly, areas considered as Least Happy Area are ID 23401 and 23402.

Based on classification result of both profiles, each classification is carried out by queries to answer spatial characteristics of poverty and happiness profiles. Table 5 and Figure 6 shows the distribution result of queries between poverty and happiness estimation based on FGT0. Areas located in quadrant of Happiest and Very Rich indicates the area profile where highest level of happiness (proportion of population distribution above the happiness threshold) along with lowest level of poverty (proportion of population distribution above the poverty line). On the other hand, areas located in quadrant of Least Happy and Very Poor indicates the area profile where the lowest level of happiness (proportion of population distribution below the happiness threshold) along with highest level of poverty (proportion of population distribution below the poverty line), and vice versa.

According to queries of poverty and happiness estimation based on FGT0, areas considered in first and second classification are dominated by regencies/city of urban areas. Areas in third and fourth classification are dominated by regencies of rural areas. There isn't area included as poorest and least happy profiles area, whereas area with ID 13471 (Yogyakarta city) is included as wealthiest and happiest profiles area.

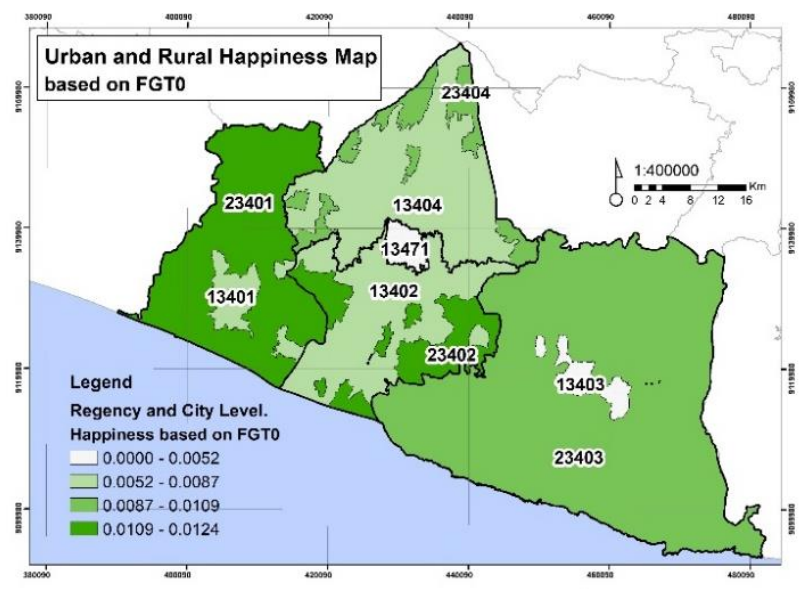

Figure 5. Happiness Map of DIY Province based on FGT0

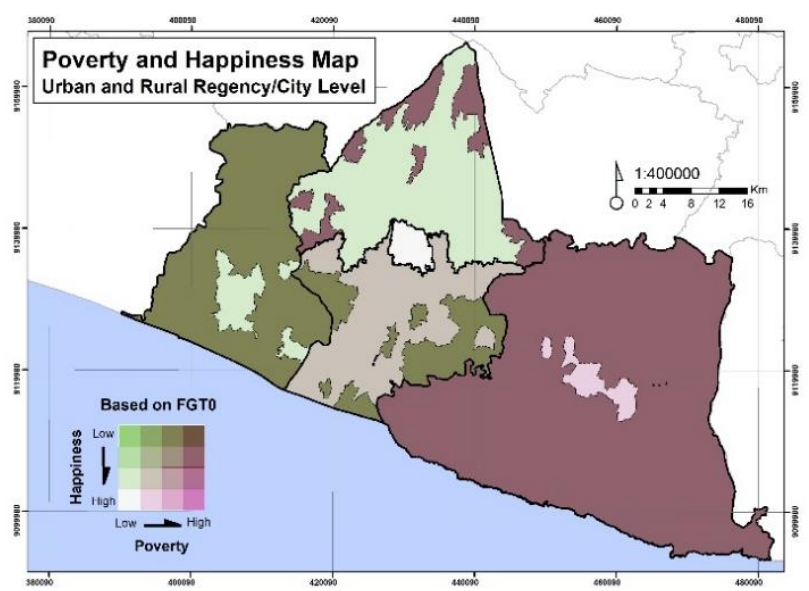

Figure 6. Poverty and Happiness Map of DIY Province based on FGT0

\begin{tabular}{|c|c|c|c|c|}
\hline $\begin{array}{c}\text { Spatial } \\
\text { profiles based } \\
\text { on FGT0 }\end{array}$ & $\begin{array}{c}\text { Poorest } \\
\text { area }\end{array}$ & $\begin{array}{c}\text { Poor } \\
\text { area }\end{array}$ & $\begin{array}{c}\text { Rich } \\
\text { area }\end{array}$ & $\begin{array}{c}\text { Very Rich/ } \\
\text { wealthiest } \\
\text { area }\end{array}$ \\
\hline $\begin{array}{c}\text { Least happy } \\
\text { area }\end{array}$ & - & $\begin{array}{c}23401 ; \\
23402\end{array}$ & - & - \\
\hline Unhappy area & $\begin{array}{c}23403 ; \\
23404\end{array}$ & - & - & - \\
\hline Happy area & - & - & 13402 & $\begin{array}{c}13401 ; \\
13404\end{array}$ \\
\hline Happiest area & - & - & 13403 & 13471 \\
\hline
\end{tabular}

Table 5. Query Distribution of Spatial Profile based on FGT0

Figure 7 show poverty estimation map and Figure 8 show happiness estimation map based on Gini index. Both maps are displayed at rural and urban regencies/city level. The classification is divided into four based on geometrical interval method. The first classification is shown with brightest color and the fourth classification is shown with darkest color.

Poverty first classification $(0.3048-0.3407)$ based on Gini index shows area with perfect equality of income. The fourth classification $(0.3712-0.3771)$ shows area with perfect inequality of income, and vice versa. Areas which are considered as perfect equality of income area are ID 13401 and 13403. Area considered as most equal of income area are ID 13471 and 23403. Area considered as most inequal of income 
area are ID 13402 and 23401. Area considered as perfect inequality of income area are ID 13404, 23402, 23404.

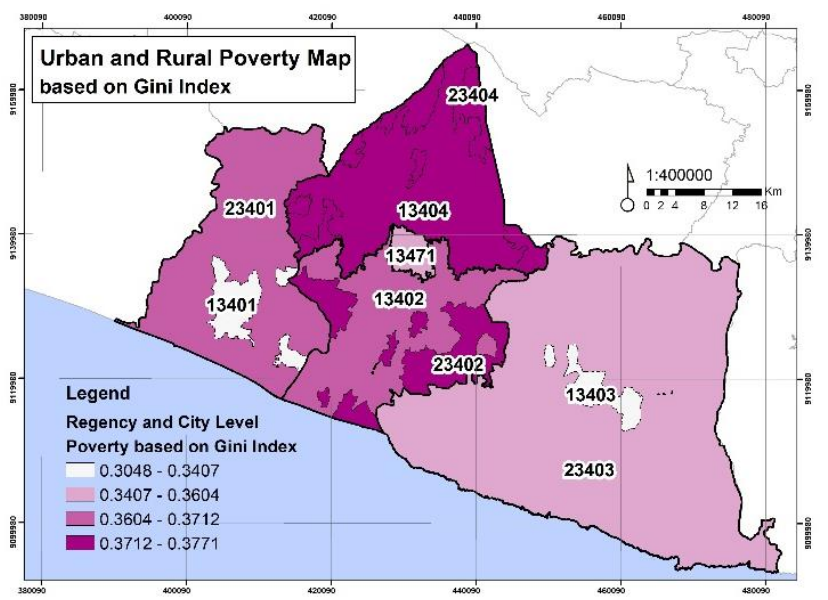

Figure 7. Poverty Map of DIY Province based on Gini index

Happiness first classification $(0.0624-0.0765)$ based on Gini index shows the area with perfect equality of happiness. The fourth classification $(0.0895-0.0923)$ shows the area with perfect inequality of happiness, and vice versa. Areas which are considered as perfect equality of happiness area are ID 13403 and 13471. Area considered as most equal of happiness are ID 13401 and 13402. Area considered as most inequal of happiness are ID 13404, 23402, 23404. Area considered as perfect inequality of happiness are ID 23401 and 23403.

Based on the classification result of both profiles, each classification is carried out by queries to answer spatial characteristics of poverty and happiness profiles. Table 6 and Figure 9 shows the distribution result of queries between poverty and happiness estimation based on Gini index. Areas located in Perfect equality of both income and happiness quadrant, indicates where there isn't disparity in the area. On the other hand, area located in quadrant of Perfect inequality of both income and happiness indicates disparities between residents is very large, and vice versa.

According to distribution result of queries, almost all areas are dispersed but still have a cluster pattern. Queries clustered pattern is shown at perfect inequality of income and most inequal of happiness. This pattern is indicated by ID 13404, 23402, 23404. Rural areas dominated inequality of happiness classification. But, there isn't area included as perfect inequality of both income and happiness areas. Urban areas dominated perfect equality of both income and happiness classification. Only area with ID 13402 (Bantul regency urban area) that have most inequal of income profiles. This means that many residents of Bantul regency urban area economically unequal but are evenly distributed in happiness. ID 13403 (Gunung Kidul regency urban area) has perfect equality of both income and happiness profiles.

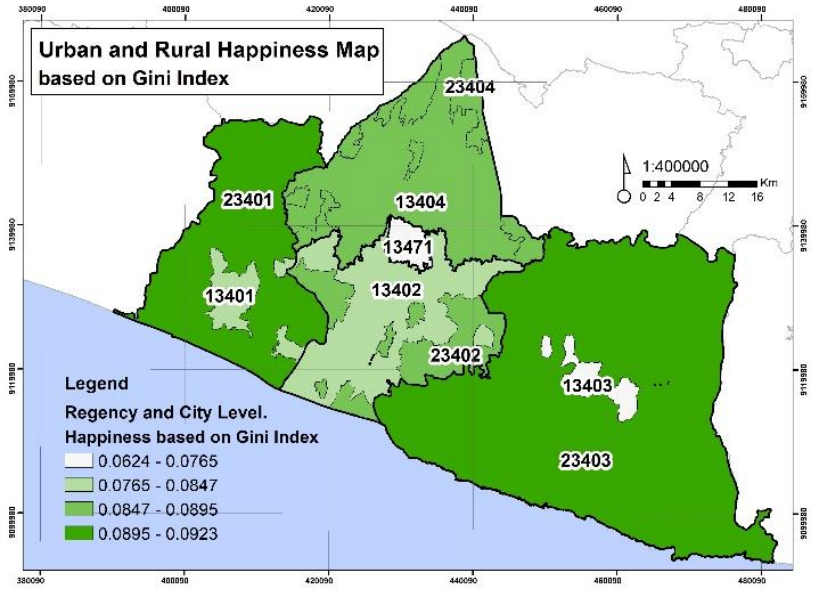

Figure 8. Happiness Map of DIY Province based on Gini index

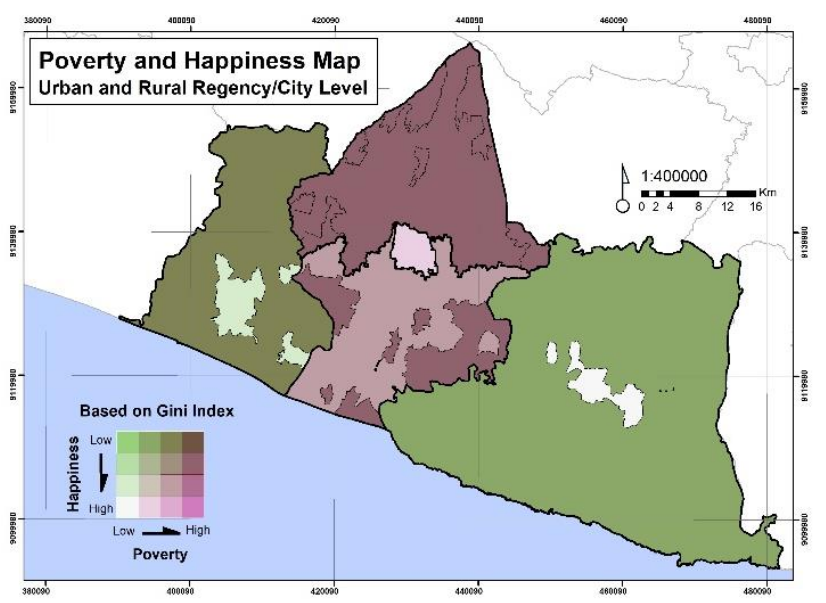

Figure 9. Poverty and Happiness Map of DIY Province based on Gini Index

\begin{tabular}{|c|c|c|c|c|}
\hline $\begin{array}{c}\text { Spatial } \\
\text { profiles based } \\
\text { on Gini }\end{array}$ & $\begin{array}{c}\text { Perfect } \\
\text { inequality } \\
\text { of income }\end{array}$ & $\begin{array}{c}\text { Most } \\
\text { inequal } \\
\text { of } \\
\text { income }\end{array}$ & $\begin{array}{c}\text { Most } \\
\text { equal of } \\
\text { income }\end{array}$ & $\begin{array}{c}\text { Perfect } \\
\text { equality of } \\
\text { income }\end{array}$ \\
\hline $\begin{array}{c}\text { Perfect } \\
\text { inequality of } \\
\text { happiness }\end{array}$ & - & 23401 & 23403 & - \\
\hline $\begin{array}{c}\text { Most inequal } \\
\text { of happiness }\end{array}$ & $\begin{array}{c}13404 ; \\
23402 ; \\
23404\end{array}$ & - & - & - \\
\hline $\begin{array}{c}\text { Most equal of } \\
\text { happiness }\end{array}$ & - & 13402 & - & 13401 \\
\hline $\begin{array}{c}\text { Perfect } \\
\text { equality of } \\
\text { happiness }\end{array}$ & - & - & 13471 & 13403 \\
\hline
\end{tabular}

Table 6. Query Distribution of Spatial Profile based on Gini index

\section{CONCLUSION}

Small area estimation result at provincial level using Podes as cencus data show twenty three household variables that are significant to poverty model and five household variables that are significant to happiness model.

Based on query of poverty and happiness estimation using FGT0, area with high poverty profile (FGT0 $0.0491-0.1076$ ) 
and low happiness profile (FTG0 $0.0087-0.0124$ ) is dominated by rural areas. Urban areas dominated low poverty profile (FTG0 $0.0082-0.0491$ ) and high happiness profile (FTG0 $0-$ 0.0087). Yogyakarta City has happiest and wealthies profiles.

Based on query of happiness estimation using Gini index, only perfect inequality of income and most unequal of happiness profiles are queries clustered, others dispersed. Further, rural areas dominated inequality of happiness profile (Gini index $0.0847-0.0923)$ and urban areas dominated perfect equality of both income (Gini index $0.3048-0.3604$ ) and happiness profiles (Gini index $0.0624-0.0847$ ). Gunung Kidul regency urban area is included as perfect equality of both income and happiness profiles.

\section{ACKNOWLEDGEMENTS}

This research was funded by Universitas Gadjah Mada's final assignment program.

\section{REFERENCES}

Akinyemi, Felicia O., Bigirimana, Florent. 2012. A Spatial Analysis of Poverty in Kigali, Rwanda using Indicators of Household Living Standard. Rwanda Journal Volume 26, Series B, 2012: Social Sciences. http://dx.doi.org/10.4314/rj.v26i1.1

Badan Pusat Statistik (BPS). 2017. Indeks Kebahagiaan 2017. CV. Dharmaputra, Jakarta. ISBN 978-602-438-145-5 (7 January 2019).

Badan Pusat Statistik (BPS). 2018. Profil Kemiskinan di Indonesia Maret 2018. Berita Resmi Statistik No 57/07/Th.XXI 16 Juli 2018 (7 January 2019).

Dolci, Claudia., Salvini, Dante., Weibel, Robert., Wiesmann, Samuel. n.d. Spatial Queries. Geographic Information Technology Training Alliance. Retrieved from http://www.gitta.info (31 May 2019)

Elbers, Chris., Lanjouw, Jean O., Lanjouw, Peter. 2002. Microlevel estimation of welfare (English). Policy, Research working paper; no. WPS 2911. Washington, DC: World Bank. http://documents.worldbank.org/curated/en/3621314687394732 97/Micro-level-estimation-of-welfare.

Elbers, Chris., Lanjouw, Jean O., Lanjouw, Peter. 2003. Micro-Level Estimation of Poverty and Inequality, Econometrica, 71, (1), 355-364. https://doi.org/10.1111/1468-0262.00399

Jaafar, Jas Laile., Idris, Mohd Awang., Ismuni, Jamal., Fei, Yoo., Jaafar, Salinah., Ahmad, Zahir., Raduan Mohd Ariff, Muhammad., Takwin, Bagus., Suprayogi Sugandi, Yogi. 2012. The Sources of Happiness to the Malaysians and Indonesians: Data from a Smaller Nation. Procedia - Social and Behavioral Sciences. 65. 549-556. 10.1016/j.sbspro.2012.11.164

QGIS Development Team, 2016. QGIS Geographic Information System, Version 2.18. Open Source Geospatial Foundation Project. https://qgis.osgeo.org

Rahayu, Theresia Puji. 2016. The Determinants of Happiness in Indonesia. Mediterranian Journal of Social Sciences vol 7(2). DOI 10.5901/mjss.2016.v7n2p393
Stanca, Luca. (2010). The Geography of Economics and Happiness: Spatial Patterns in the Effects of Economic Conditions on Well-Being. Social Indicators Research. 99. 115133. $10.1007 / \mathrm{s} 11205-009-9571-1$

Suryahadi, Asep. Wenefrida Widyanti. Daniel Perwira et al. 2003. Developing a Poverty Map for Indonesia: An Initiatory Work in Three Provinces. Technical Report. SMERU Research Institute.

World Bank. 2010. Small Area Estimation of Poverty in Rural Bhutan (English). Washington, DC: World Bank. http://documents.worldbank.org/curated/en/2218714682009503 59/Small-area-estimation-of-poverty-in-rural-Bhutan

World Bank Group, 2015. Software for Poverty Mapping (PovMap), Version 2.0. Open Source. www.iresearch.worldbank.org (20 April 2019).

World Bank. 2018. Spatial analysis of poverty: Combining geospatial data and survey data to study regional inequality in Ghana: Spatial analysis of poverty in Ghana (English). Washington, DC: World Bank. http://documents.worldbank.org/curated/en/8921515466429538 99/Spatial-analysis-of-poverty-in-Ghanaquery

Xiang, N. \& Han, X. J. Definition and Contents of Spatial Analysis. 1997. Journal of Central South University of Technology. 4: 28. https://doi.org/10.1007/s11771-997-0025-0

Yuliasih, Eko., Susanto, Irwan. 2010. Determining Poverty Map Using Small Area Estimation Method. Seminar Nasional Matematika 2010. Proceeding. Sebelas Maret University.

Zhao, Qinghua., Lanjouw, Peter. Using PovMap2 a Users's Guide. n.d. World Bank http://iresearch.worldbank.org/PovMap/PovMap2/PovMap2Ma nual.pdf

Revised August 2019 
The International Archives of the Photogrammetry, Remote Sensing and Spatial Information Sciences, Volume XLII-4/W16, 2019 6th International Conference on Geomatics and Geospatial Technology (GGT 2019), 1-3 October 2019, Kuala Lumpur, Malaysia

\section{APPENDIX}

Appendix 1. Results of OLS and GLS Podes - Susenas DIY Province

\begin{tabular}{|c|c|c|c|c|}
\hline \multicolumn{5}{|c|}{ Dependent Variable: Log Per Capita Expenditure } \\
\hline Variable & OLS & S.E & GLS & S.E \\
\hline Intercept & 13.8433 & 0.0842 & 13.8167 & 0.0737 \\
\hline BB_1 & -0.2492 & 0.0446 & -0.2507 & 0.0337 \\
\hline BB_3 & -0.5376 & 0.0529 & -0.5528 & 0.0426 \\
\hline CURIKE_1 & -0.9969 & 0.5899 & -1.0601 & 0.0946 \\
\hline CURI_1 & 0.1975 & 0.0765 & 0.2371 & 0.0716 \\
\hline JAMKES_1 & -0.2719 & 0.0215 & -0.262 & 0.022 \\
\hline KUD_1 & 0.073 & 0.039 & 0.0812 & 0.0401 \\
\hline LU_HEAD_1 & -0.2405 & 0.0305 & -0.2134 & 0.0297 \\
\hline LU_HEAD_3 & -0.2858 & 0.0365 & -0.2554 & 0.0368 \\
\hline LU_HEAD_4 & -0.2409 & 0.0326 & -0.2055 & 0.0325 \\
\hline LU_HEAD_6 & -0.2345 & 0.0264 & -0.2153 & 0.0262 \\
\hline MCK_1 & 0.3527 & 0.0655 & 0.3841 & 0.0634 \\
\hline MCK_2 & 0.3845 & 0.0547 & 0.4228 & 0.0513 \\
\hline MCK_3 & 0.4095 & 0.1244 & 0.3994 & 0.1204 \\
\hline SUAM_2 & -0.1407 & 0.0404 & -0.0885 & 0.0363 \\
\hline SUAM_3 & -0.3708 & 0.0522 & -0.3754 & 0.053 \\
\hline SUAM_4 & -0.4168 & 0.0321 & -0.4238 & 0.0321 \\
\hline SUAM_5 & -0.5368 & 0.1167 & -0.4932 & 0.1139 \\
\hline TAPT_1 & 0.3077 & 0.0531 & 0.286 & 0.0485 \\
\hline TAPT_2 & 0.1551 & 0.0964 & 0.1125 & 0.0954 \\
\hline TAPT_3 & 0.2948 & 0.0645 & 0.2915 & 0.0588 \\
\hline TBS_1 & -0.1528 & 0.0228 & -0.1495 & 0.0238 \\
\hline TELE_1 & 0.591 & 0.0436 & 0.5754 & 0.0466 \\
\hline TELE_2 & 0.2955 & 0.0244 & 0.2863 & 0.0239 \\
\hline MSE & 0.3387 & & & \\
\hline RMSE & 0.582 & & & \\
\hline R2 & 0.4504 & & & \\
\hline Adjusted R2 & 0.447 & & & \\
\hline $\mathrm{F}$ & 131.7457 & & & \\
\hline
\end{tabular}

Appendix 2. Results of OLS and GLS Podes - SPTK DIY Province

\begin{tabular}{|c|c|c|c|c|}
\hline \multicolumn{5}{|c|}{ Dependent Variable: Log Overall Life Satisfaction Scale } \\
\hline Variable & OLS & S.E & GLS & S.E \\
\hline Intercept & 1.9941 & 0.0192 & 1.9879 & 0.0189 \\
\hline BB_1 & 0.0567 & 0.0134 & 0.0549 & 0.0153 \\
\hline LU_HEAD_1 & -0.0195 & 0.0139 & -0.0266 & 0.0141 \\
\hline SUAM_4 & -0.0323 & 0.011 & -0.0306 & 0.0081 \\
\hline SUAM_5 & -0.0525 & 0.0286 & -0.0432 & 0.0276 \\
\hline TELE_1 & 0.0409 & 0.0175 & 0.0471 & 0.0188 \\
\hline MSE & \multicolumn{2}{|l|}{0.0232} & \\
\hline RMSE & \multicolumn{2}{|l|}{0.1523} & & \\
\hline R2 & \multicolumn{2}{|l|}{0.0672} & & \\
\hline Adjusted R2 & \multicolumn{2}{|l|}{0.062} & & \\
\hline $\mathrm{F}$ & \multicolumn{2}{|l|}{12.8479} & & \\
\hline
\end{tabular}

Appendix 3. Variable codes description which contribute significantly to the models

\begin{tabular}{|l|l|}
\multicolumn{1}{c|}{ Variable } & \multicolumn{1}{c|}{ significantly to the models } \\
\hline BB_1 & Cooking fuel using electricity/gas \\
\hline BB_3 & $\begin{array}{l}\text { Cooking fuel } \\
\text { charcoal/briquettes/firewood }\end{array}$ \\
\hline CURIKE_1 & Theft with violence in the neighbourhood \\
\hline CURI_1 & Theft in the neighbourhood \\
\hline JAMKES_1 & Has state and regional health insurance \\
\hline KUD_1 & Recipient of cooperation credit \\
\hline
\end{tabular}

\begin{tabular}{|l|l|}
\hline LU_HEAD_1 & $\begin{array}{l}\text { Household head occupation in } \\
\text { agricultural/forestry/fisheries sector }\end{array}$ \\
\hline LU_HEAD_3 & $\begin{array}{l}\text { Household head occupation in processing } \\
\text { industry sector }\end{array}$ \\
\hline LU_HEAD_4 & Household head occupation in trading sector \\
\hline LU_HEAD_6 & Household head occupation in services sector \\
\hline MCK_1 & $\begin{array}{l}\text { Bathing/washing/toilet facilities using tap } \\
\text { water }\end{array}$ \\
\hline MCK_2 & Bathing, washing, toilet facilities using well \\
\hline MCK_3 & $\begin{array}{l}\text { Bathing, washing, toilet facilities using water } \\
\text { spring/surface water }\end{array}$ \\
\hline SUAM_2 & Drinking water using refill water \\
\hline SUAM_3 & Drinking water using tap water \\
\hline SUAM_4 & Drinking water using well \\
\hline SUAM_5 & Drinking water using spring/surface water \\
\hline TAPT_1 & Disposal feces using disposal installation/tank \\
\hline TAPT_2 & Disposal feces using rice field/pool/river \\
\hline TAPT_3 & Disposal feces using ground hole \\
\hline TBS_1 & Waste disposal by burning \\
\hline TELE_1 & Has landline \\
\hline TELE_2 & Household head has cellular phone \\
\hline
\end{tabular}

